\title{
KARAKTERISTIK DISTRIBUSI DAN HABITAT Anopheles spp. DI KELURAHAN KEMELAK BINDUNG LANGIT, KABUPATEN OGAN KOMERING ULU TAHUN 2018
}

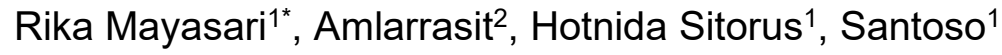 \\ ${ }^{1}$ Balai Penelitian dan Pengembangan Kesehatan Baturaja \\ JI. A.Yani KM.7 Kemelak Baturaja, 32111, Kabupaten Ogan Komering Ulu, Sumatera Selatan, Indonesia \\ 2Jurusan Biologi Fakultas MIPA Universitas Sriwijaya \\ Jln.Palembang-Prabumulih KM.32, Indralaya, Ogan Ilir, Sumatera Selatan, Indonesia
}

\begin{abstract}
Many factors can influence the incidence of malaria. These factors come from changes in environmental conditions itself. Environmental conditions affect the density of the Anopheles population inside the house who comes into contact with humans. One of the environmental factor is air temperature, and in warm condition could accelerate life cycle of mosquitoes thereby increasing mosquitoes density inside the house. The greater the density of mosquitoes per person per hour will increase the frequency of contact between vectors and humans. Research objectives was to identify and map potential breeding habitats of Anopheles larvae. The study was conducted in a cross-sectional design in Kelurahan Kemelak Bindung Langit, Baturaja Timur Subdistrict in August 2018 as the population is a potential breeding habitat for Anopheles larvae such as rice fields, ponds, swamps, slow river flow and ditches. Data collection was carried out by observing breeding habitat of Anopheles larvae, collecting larvae or pupae and record biological and physical condition. Observation of Anopheles larvae was carried out by dipping all larvae or pupae that observed visually. The results of this study show that the types of Anopheles breeding habitats in Kelurahan Kemelak Bindung Langit were swamps and ponds with larvae populations density ranging from 30 - 110 individuals. The water temperature ranges from $29^{\circ} \mathrm{C}-30^{\circ} \mathrm{C}$. The characteristic of all Anopheles breeding habitat were not exposed to direct sunlight, with a $\mathrm{pH}$ of 6 and area rnages from 21-240 $\mathrm{m}^{2}$.
\end{abstract}

Keywords : Anopheles, breeding habitats, Ogan Komering Ulu.

\section{CHARACTERISTIC OF DISTRIBUTION AND HABITAT OF Anopheles spp. IN KELURAHAN KEMELAK BINDUNG LANGIT, OGAN KOMERING ULU REGENCY IN 2018}

\begin{abstract}
Abstrak
Banyak faktor dapat mempengaruhi kejadian malaria. Faktor tersebut berasal dari perubahan kondisi lingkungan itu sendiri. Kondisi lingkungan mempengaruhi kepadatan Anopheles spp. di dalam rumah yang kontak dengan manusia. Kondisi tersebut berupa suhu udara. Suhu udara yang hangat mempercepat siklus hidup nyamuk sehingga meningkatkan kepadatan nyamuk di dalam rumah. Besarnya kepadatan nyamuk per orang per jam akan meningkatkan frekuensi kontak antara vektor dan manusia. Penelitian ini bertujuan untuk mengidentifikasi serta memetakan habitat perkembangbiakan potensial larva Anopheles. Penelitian dilakukan secara potong lintang di Kelurahan Kemelak Bindung Langit Kecamatan Baturaja Timur pada bulan Agustus 2018. Sebagai populasi adalah habitat perkembangbiakan larva Anopheles yang potensial seperti sawah, kolam, rawa, aliran sungai yang tidak deras dan parit. Pengumpulan data dilakukan dengan mengamati habitat potensial larva Anopheles yang terdiri dari jumlah larva dan mengamati lingkungan fisik biologinya. Pengamatan larva Anopheles dilakukan dengan metode pencidukan larva. Hasil dari penelitian ini adalah jenis habitat perkembangbiakan larva Anopheles di Kelurahan Kemelak Bindung Langit adalah rawa dan kolam dengan kepadatan larva berkisar 30-110 ekor. Suhu air pada habitat perkembangbiakan
\end{abstract}


berkisar $29^{\circ} \mathrm{C}-30^{\circ} \mathrm{C}$. Seluruh habitat perkembangbiakan larva Anopheles tidak terkena paparan sinar matahari langsung. Kadar garam pada habitat perkembangbiakan yaitu 0\%. Luas habitat berkisar $21 \mathrm{~m}^{2}-2400 \mathrm{~m}^{2}$, dengan memiliki pH masing- masing pada habitat yaitu 6 .

Kata Kunci : Anopheles, habitat perkembangbiakan, Ogan Komering Ulu.

Naskah masuk: 4 Mei 2020; Review: 30 September 2020; Layak Terbit: 11 Januari 2021

*Alamat korespondensi penulis pertama: e-mail: monde_cute@yahoo.co.id; Telp: (0735) 325303

\section{PENDAHULUAN}

Malaria ditularkan oleh nyamuk Anopheles spp. yang mana perilakunya selalu beradaptasi dengan perubahan iklim dan ekologi serta kegiatan manusia di sekitarnya. ${ }^{1}$ Nyamuk Anopheles dapat membawa parasit malaria di dalam tubuhnya, yang disebut Plasmodium. Ada 4 jenis Plasmodium yang dapat menyebabkan malaria pada manusia, yaitu Plasmodium vivax, Plasmodium ovale, Plasmodium malariae dan Plasmodium falciparum.

Penyakit ini mempengaruhi tingginya angka kematian dan kesakitan ibu hamil, bayi dan anak balita. Setiap tahun lebih dari 500 juta penduduk dunia terinfeksi malaria dan lebih dari satu juta orang meninggal dunia. ${ }^{2}$ Annual Parasite Incidence (API) di Indonesia sebesar 0,99 per 1.000 penduduk. Secara nasional angka kesakitan malaria selama tahun 2009-2017 cenderung menurun. Meskipun demikian beberapa provinsi masih menunjukkan nilai API > 1 per 1.000 penduduk seperti Provinsi Papua, Papua Barat dan Nusa Tenggara Timur. ${ }^{2}$ Sekitar 70 spesies Anopheles spp. telah teridentifikasi sebagai vektor malaria di dunia. $^{3}$ Dua puluh empat spesies di antaranya ada di Indonesia ${ }^{4}$ yang sangat bervariasi baik dari biologis, pola menghisap darah, respon terhadap insektisida maupun habitatnya.

Pada tahun 2012, nilai API Provinsi Sumsel sebesar 0,62 per 1000 penduduk. Salah satu kabupaten endemis malaria di Provinsi Sumsel adalah Kabupaten Ogan Komering Ulu (OKU). Hasil pemeriksaan menunjukkan penderita positif malaria sebesar 103 orang (laki-laki 65 orang dan perempuan 38 orang) dengan nilai API sebesar 0,3 per 1000 penduduk (laki-laki
0,2 per 1000 penduduk dan perempuan 0,1 per 1000 penduduk) di tahun $2018 .^{5}$

Pada tahun 2017 ditemukan kasus penyakit malaria sebanyak 264 kasus, terjadi peningkatan 24\% dari tahun 2016 . Kasus malaria di Kabupaten OKU tersebar di beberapa kelurahan, salah satunya adalah Kelurahan Kemelak dengan jumlah kasus malaria terdapat 6 kasus (tahun 2017). Data Dinas Kesehatan Kabupaten OKU menyatakan terdapat 384 kasus klinis termasuk juga di daerah Kelurahan Kemelak. ${ }^{6}$ Sebagai penyakit bersumber dari vektor, yaitu nyamuk Anopheles. Kondisi lingkungan sangat berpengaruh terhadap keberadaan dan kehidupan nyamuk Anopheles sebagai vektor malaria. Dengan demikian, penting adanya upaya pengendalian malaria ditinjau dari aspek lingkungan.

Banyak faktor yang dapat mempengaruhi kejadian malaria. Faktor tersebut berasal dari perubahan kondisi lingkungan itu sendiri. Lingkungan biologis merupakan suatu karakteristik lingkungan yang mempengaruhi tempat perindukan nyamuk untuk berkembang, berbagai tumbuhan air yang mempengaruhi perkembangbiakan nyamuk malaria, misalnya lumut dan ganggang. Selain tumbuhan air, tumbuhan yang ada di darat juga mempengaruhi perkembangbiakan nyamuk malaria misalnya tumbuhan yang besar yang menghalangi masuknya sinar matahari ke tempat perindukan, sehingga menyebabkan pencahayaan akan rendah, suhu rendah dan kelembaban akan tinggi. Kondisi seperti inilah yang sangat disenangi oleh nyamuk untuk beristirahat setelah menghisap darah hospes sambil menunggu proses pematangan telurnya. ${ }^{7}$ 
Habitat perkembangbiakan menjadi potensial bagi siklus kehidupan nyamuk Anopheles spp. untuk menjadi vektor malaria dikarenakan dukungan kondisi lingkungan fisik, kimia, dan biologi. Lingkungan tersebut meliputi tipe habitat, suhu, pH air, kekeruhan, sinar matahari, aliran air, curah hujan, angin, keberadaan vegetasi, keberadaan hewan predator pemakan larva, salinitas, kadar $\mathrm{Fe}$, dan lain sebagainya. Mengetahui karakteristik ekologi habitat perkembangbiakan larva Anopheles spp. merupakan salah satu langkah untuk memutus rantai penularan penyakit malaria melalui penanganan dari habitat vektor. $^{8}$

Selain itu juga jarak habitat ke rumah penduduk mempengaruhi kejadian malaria. Tambak dan lagun merupakan tipe habitat perkembangbiakan yang ditemukan dengan kisaran dari rumah penduduk 15-500 meter dengan spesies potensial vektor yaitu Anopheles subpictus dan $A n$. sundaicus. Hal ini menunjukkan bahwa rumah penduduk mempunyai risiko tinggi dalam penularan malaria karena terletak dalam radius jarak terbang Anopheles spp. Radius jarak terbang aktif Anopheles spp. adalah 100-200 meter. $^{9}$

Hasil penangkapan nyamuk dewasa yang pernah dilakukan di Kelurahan Kemelak menunjukan bahwa di Kelurahan Kemelak di temukan keberadaan nyamuk Anopheles dewasa, sedangkan data habitat potensial nyamuk Anopheles di Kelurahan Kemelak belum ada. Tujuan penelitian ini adalah mengidentifikasi habitat perkembangbiakan potensial larva Anopheles dan pemetaan habitat tersebut. Data ini diharapkan dapat melengkapi data entomologi.

\section{METODE}

Penelitian ini dilakukan Kelurahan Kemelak, Kecamatan Baturaja Timur, Kabupaten OKU. Penelitian dilaksanakan pada bulan Agustus 2018. Penelitian ini menggunakan desain cross sectional. Populasi dalam penelitian ini adalah seluruh habitat perkembangbiakan larva Anopheles yang potensial seperti sawah, kolam, rawa, aliran sungai yang tidak deras dan parit di Kelurahan Kemelak, sedangkan inklusi sampel adalah habitat potensial yang pada saat penelitian terdapat air atau tidak kering. Pengumpulan data yang dilakukan adalah pengamatan habitat potensial larva Anopheles yang terdiri dari jumlah larva dan pengamatan lingkungan fisik dan biologinya. Pengamatan larva Anopheles dilakukan dengan metode pencidukan larva. Pencidukan dilakukan sebanyak 10 kali untuk tiap habitat. Data pengamatan lingkungan fisik dan biologi dilakukan dengan cara observasi dan dilakukan pencatatan. Identifikasi Anopheles dilakukan dengan cara me rearing/memelihara larva hingga menjadi nyamuk, baru kemudian diidentifikasi, berpedoman buku kunci nyamuk Anopheles dewasa di Sumatera-Kalimantan.

Analisis data dilakukan secara deskriptif dan ditampilkan dalam bentuk tabel dan gambar. Analisis data hasil pencidukan larva menggunakan rumus sebagai berikut ${ }^{10}$ :

Kepadatan larva $=\frac{\text { Jumlah larva yang didapat }}{\text { Jumlah cidukan }}$

\section{HASIL}

Pengamatan dilakukan di 25 perairan yang berpotensi sebagai habitat larva Anopheles di Kelurahan Kemelak (Tabel 1). Habitat yang ditemukan positif larva Anopheles sebanyak 4 lokasi yaitu 2 sawah dan 2 kolam, selain itu ada sebanyak 14 habitat yang positif larva non Anopheles. Hasil penelitian menunjukkan bahwa spesies larva yang ditemukan adalah Anopheles barbirostis, dengan densitas 30110 larva.

Pengamatan terhadap lingkungan fisik habitat yang positif larva Anopheles spp. (Tabel 1) menunjukkan bahwa suhu air berkisar $29-30^{\circ} \mathrm{C}$, salinitas $0 \%$, $\mathrm{pH} 6$ dan perairan tersebut tidak terkena sinar matahari langsung. Pada pengamatan lingkungan biologi, diketahui bahwa semua habitat terdapat tumbuhan air dan sebagian besar terdapat keberadaan ikan. Jenis-jenis habitat perkembangbiakan yang ditemukan positif larva Anopheles dapat dilihat pada Gambar 1. Jarak keberadaan habitat yang positif tersebut berkisar $7-30 \mathrm{~m}$ dengan rumah penduduk terdekat. 
Tabel 1. Habitat perkembangbiakan potensi larva nyamuk di Kelurahan Kemelak Bindung Langit

\begin{tabular}{|c|c|c|c|c|c|c|c|c|c|c|c|c|c|}
\hline \multirow[b]{2}{*}{ 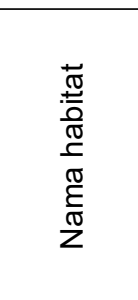 } & \multirow[b]{2}{*}{ 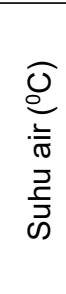 } & \multirow[b]{2}{*}{ 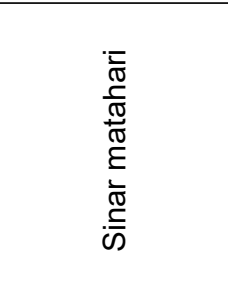 } & \multirow[b]{2}{*}{ 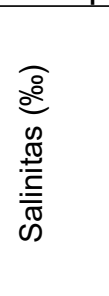 } & \multirow[b]{2}{*}{ 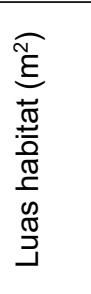 } & \multirow[b]{2}{*}{$\begin{array}{l}. \bar{\Xi} \\
\text { I } \\
\text { Q }\end{array}$} & \multirow[b]{2}{*}{$\begin{array}{c}\text { Jarak } \\
\text { rumah } \\
\text { terdekat } \\
\quad(\mathrm{m})\end{array}$} & \multirow[b]{2}{*}{$\begin{array}{l}\text { Keberadaan } \\
\text { Ikan } \\
\text { pemakan } \\
\text { larva }\end{array}$} & \multirow[b]{2}{*}{ 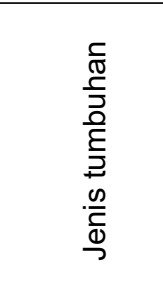 } & \multicolumn{2}{|c|}{$\begin{array}{l}\text { Keberadaan } \\
\text { larva }\end{array}$} & \multirow[b]{2}{*}{ 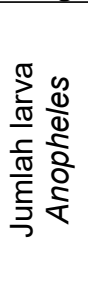 } & \multirow[b]{2}{*}{ 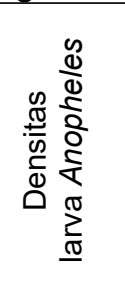 } & \multirow[b]{2}{*}{$\begin{array}{l}\frac{d}{d} \\
\frac{d}{d} \\
\frac{2}{2} \\
\frac{1}{4} \\
\frac{d}{0} \\
\frac{d}{d} \\
\frac{0}{0}\end{array}$} \\
\hline & & & & & & & & & $\frac{\frac{2}{d}}{\frac{d}{2}}$ & $\frac{\frac{d}{d}}{\frac{d}{d}} \frac{\frac{d}{d}}{\frac{1}{4}}$ & & & \\
\hline Sawah 1 & 30 & Langsung & 0 & 4 & 6 & 7 & Ada & Padi & - & - & 0 & 0 & \\
\hline Sawah 2 & 28 & Langsung & 0 & 1 & 6 & 8 & Tidak ada & Padi & - & + & 0 & 0 & \\
\hline Sawah 3 & 28 & Langsung & 0 & 1 & 6 & 25 & Ada & Padi & - & - & 0 & 0 & \\
\hline Sawah 4 & 28 & Langsung & 0 & 1 & 6 & 20 & Ada & - & - & - & 0 & 0 & \\
\hline Sawah 5 & 28 & Langsung & 0 & 1 & 6 & 40 & Tidak ada & - & - & + & 0 & 0 & \\
\hline Sawah 6 & 28 & Tidak langsung & 0 & 1 & 6 & 2 & Ada & Padi & - & - & 0 & 0 & \\
\hline Rawa 1 & 29 & Langsung & 0 & 100 & 6 & 2 & Ada & Kangkung & - & + & 0 & 0 & \\
\hline Rawa 2 & 30 & Tidak langsung & 0 & 120 & 6 & 7 & Ada & Kangkung & + & - & 70 & 7 & An. barbirostris \\
\hline Rawa 3 & 29 & Langsung & 0 & 105 & 6 & 1 & Ada & Rumput & - & + & 0 & 0 & \\
\hline Rawa 4 & 29 & Langsung & 0 & 75 & 6 & 8 & Ada & - & - & + & 0 & 0 & \\
\hline Rawa 5 & 28 & Tidak langsung & 0 & 224 & 6 & 19 & Ada & - & - & + & 0 & 0 & \\
\hline Rawa 6 & 28 & Langsung & 0 & 55 & 6 & 11 & Ada & Kangkung & - & + & 0 & 0 & \\
\hline Rawa 7 & 29 & Tidak langsung & 0 & 80 & 6 & 30 & Tidak ada & Kangkung & + & - & 30 & 3 & An. barbirostris \\
\hline Rawa 8 & 29 & Langsung & 0 & 32 & 6 & 40 & Tidak ada & Kangkung & - & + & 0 & 0 & \\
\hline Rawa 9 & 29 & Langsung & 0 & 6 & 6 & 30 & Ada & - & - & + & 0 & 0 & \\
\hline Kolam 1 & 30 & Langsung & 0 & 60 & 6 & 4 & Ada & Kangkung & & + & 0 & 0 & \\
\hline Kolam 2 & 29 & Tidak langsung & 0 & 21 & 6 & 12 & Ada & Kangkung & + & + & 100 & 10 & An. barbirostris \\
\hline Kolam 3 & 26 & Tidak langsung & 0 & 100 & 6 & 5 & Tidak ada & Kangkung & - & + & 0 & 0 & \\
\hline Kolam 4 & 27 & Tidak langsung & 0 & 20 & 6 & 6 & Ada & Kangkung & - & - & 0 & 0 & \\
\hline Kolam 5 & 27 & Tidak langsung & 0 & 20 & 6 & 6 & Ada & Kangkung & - & - & 0 & 0 & \\
\hline Kolam 6 & 30 & Tidak langsung & 0 & 2400 & 6 & 30 & Ada & Rumput & + & - & 11 & 110 & An. Barbirostris \\
\hline Kolam 7 & 28 & Langsung & 0 & 21 & 6 & 10 & Ada & Kangkung & - & + & 0 & 0 & \\
\hline Kolam 8 & 28 & Langsung & 0 & 20 & 6 & 20 & Ada & Kangkung & - & + & 0 & 0 & \\
\hline Parit 1 & 28 & Langsung & 0 & 18 & 6 & 40 & Ada & - & - & - & 0 & 0 & \\
\hline Parit 2 & 28 & Langsung & 0 & 50 & 6 & 6 & Ada & - & - & - & 0 & 0 & \\
\hline
\end{tabular}




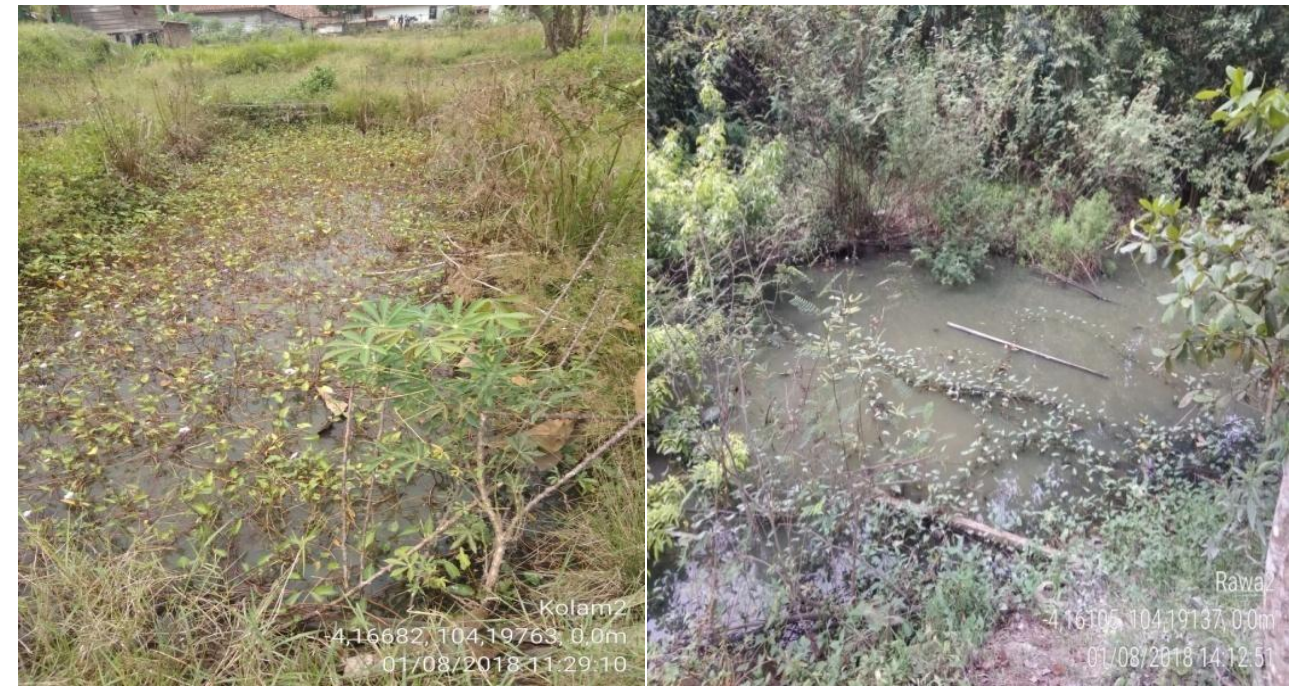

A

B

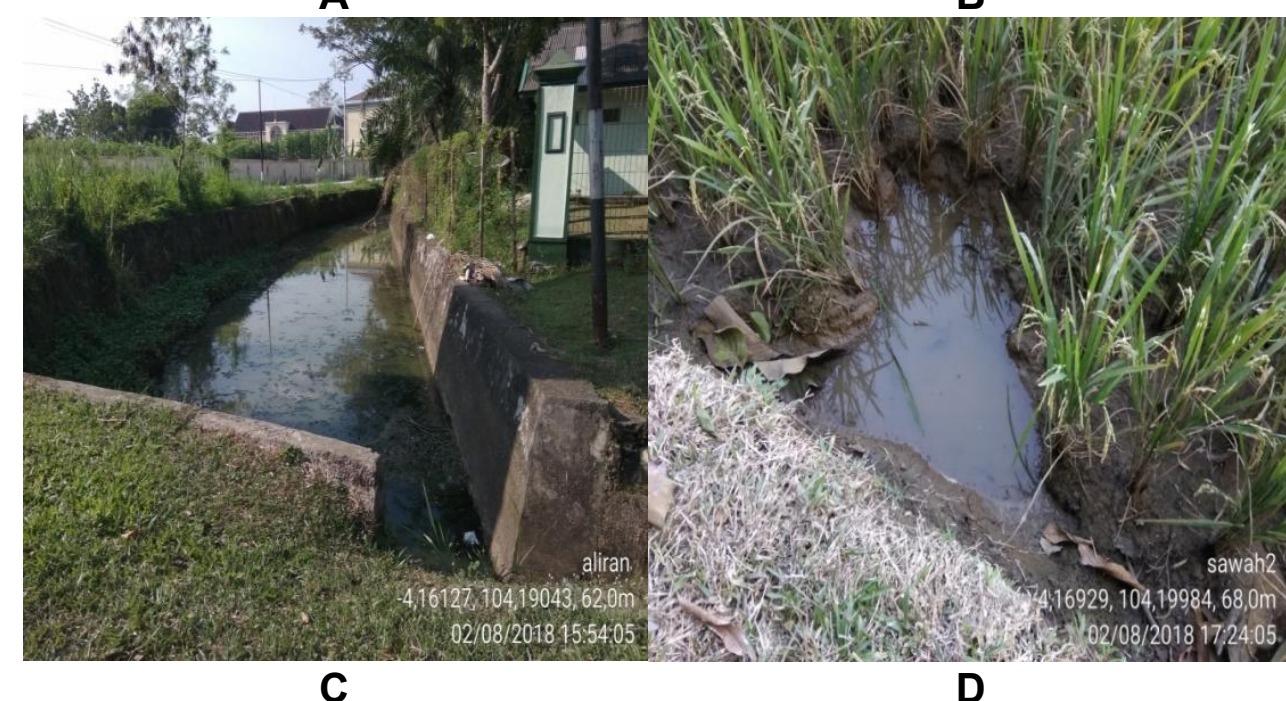

C

$$
\text { D }
$$

Gambar 1. Habitat perkembangbiakan potensial larva Anopheles, (A) Kolam ikan terbengkalai, (B) Rawa, (C) Parit dan (D) Sawah yang ditemukan di Kelurahan Kemelak, Kecamatan Baturaja Kabupaten OKU 


\section{Pemetaan habitat perkembangbiakan larva Anopheles}

$\begin{array}{ccr}\text { Identifikasi } & \text { posisi } & \begin{array}{r}\text { habitat } \\ \text { larva }\end{array} \\ \text { Anopheles }\end{array}$

berdasarkan pada titik koordinat menghasilkan titik-titik habitat perkembangbiakan nyamuk yang tersebar dalam peta pada Gambar 2.

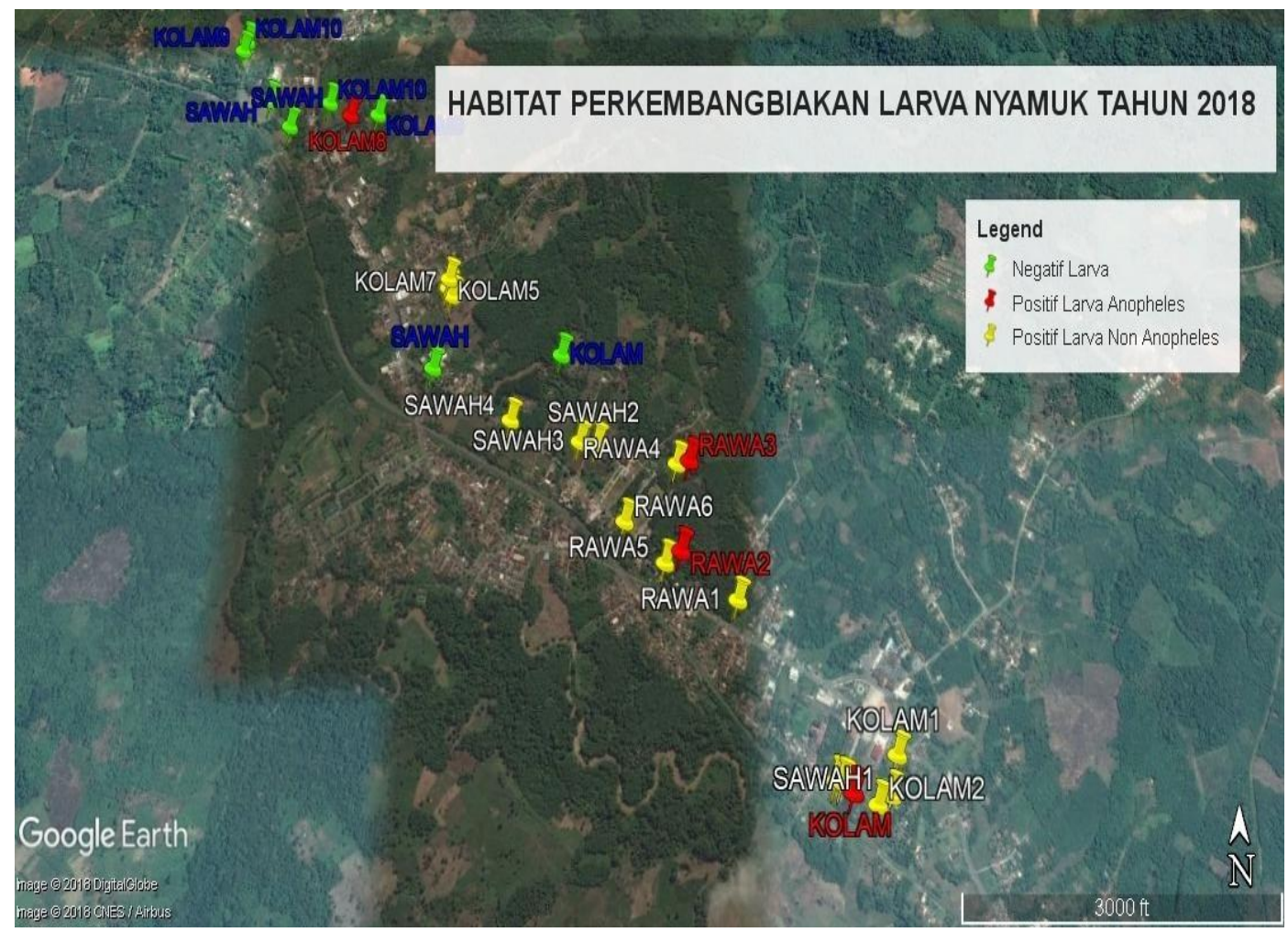

Gambar 2. Pemetaan habitat perkembangbiakan larva Anopheles.

\section{BAHASAN}

Kepadatan larva Anopheles yang ditemukan pada beberapa habitat perkembangbiakan bervariasi tergantung tempat penempatan telur. Pemilihan tempat meletakan telur di lakukan oleh nyamuk betina dewasa pada tempat yang potensial sebagai tempat perkembangbiakanya. Berdasarkan pengamatan tipe habitat perkembangbiakan di Kelurahan Kemelak menunjukkan bahwa kolam ikan yang terbengkalai dan rawa merupakan tipe habitat perkembangbiakan yang paling potensial bagi larva Anopheles. Begitu juga dengan penelitian yang dilakukan Sugiarto dkk bahwasanya ditemukan Anopheles setiap bulan dengan frekuensi $100 \%$ pada habitat tambak ikan yang terbengkalai sedangkan pada rawa hanya frekuensi $55,6 \%$ yang artinya lebih sedikit Anopheles ditemukan di rawa dibandingkan pada kolam ikan yang terbengkalai. ${ }^{11}$ Shinta et. al. melaporkan bahwa rawa-rawa di
Kecamatan Belakang Padang, Batam, Kepulauan Riau merupakan habitat potensial larva Anopheles sundaicus dan An. letifer. ${ }^{12}$ Begitu juga dengan penelitian yang dilakukan oleh Muhammad et al. bahwasanya yang menjadi tempat perkembangbiakan larva An. Letifer adalah kolam dan tambak. Kolam tersebut merupakan kolam yang terbengkalai bekas pengolahan tambang emas sehingga menjadi habitat nyamuk, sedangkan tambak ditumbuhi tanaman air berupa rumputrumputan dan kangkung. Kondisi ini sesuai dengan penelitian yang dilakukan Sugiarto dkk yang menyatakan bahwa tambak yang ditumbuhi tanaman air berupa rumputrumputan dan lumut sesuai untuk habitat larva Anopheles. ${ }^{11}$ Lumut sebagai sumber makanan dan rerumputan menjadi tempat persembunyian larva dari predator pemangsa larva.

Pada penelitian yang dilakukan oleh Junus dkk di Tabalong, Kalimantan Selatan 
dikatakan bahwa tempat perkembangbiakan larva Anopheles sp berupa genangan air di bawah atau di samping rumah dan ditumbuhi-tanaman kangkung dan enceng gondok. ${ }^{13}$

Pada penelitian ruben dkk, larva Anopheles anullaris dan An. barbirostris diketahui menyukai habitat berupa kubangan kerbau dan bekas jejak tapak kaki kerbau dengan derajat keasaman $\mathrm{pH}$ sebesar 8 dan salinitas sebesar $1,5 \mathrm{ppm}^{14}$ Tempat perkembangbiakan Anopheles spp. merupakan tempat yang dipergunakan oleh nyamuk Anopheles untuk berkembangbiak memulai proses siklus hidupnya hingga menjadi nyamuk. ${ }^{15}$ Jenis perairan yang dimanfaatkan untuk perkembangbiakan Anopheles berbedabeda. Beberapa spesies larva Anopheles menyukai hidup di sawah, kolam, mata air dan genangan air yang bersifat sementara atau di rawa-rawa yang permanen dan lainlain yang airnya tawar. Sebagian besar lainnya hidup di habitat rawa-rawa, muara sungai, lagun yang airnya asin 1516

Hasil penelitian mengenai larva Anopheles di Kelurahan Kemelak, OKU menyatakan bahwa ada 4 tipe perairan potensial sebagai habitat larva Anopheles spp. yang ada di wilayah penelitian, yaitu sawah, rawa-rawa, kolam dan parit. Pada saat penelitian, tipe perairan yang positif ditemukan terdapat larva Anopheles spp. adalah rawa-rawa dan kolam. Di dalam penelitian-penelitian tentang habitat larva Anopheles spp., sering disebut sawah dan parit juga merupakan habitat bagi Anopheles spp., tetapi pada saat penelitian ini tidak dijumpai larva Anopheles spp., hanya ada larva-larva non Anopheles spp. Kemungkinan besar pada saat penelitian dilakukan adalah musim kemarau sehingga keberadaan air sangat minim sehingga perairan yang habitat juga sedikit, hal ini mempengaruhi jumlah dan keanekaragaman populasi Anopheles spp. Suhu habitat perkembangbiakan larva Anopheles di lokasi penelitian berkisar 26$30^{\circ} \mathrm{C}$. Hal ini sesuai dengan penelitian Kordi dan Tancung yang memperoleh hasil pengukuran suhu air berada pada kisaran $26-32^{\circ} \mathrm{C}$, ini merupakan suhu ideal bagi kehidupan larva Anopheles spp. karena derajat suhu mempengaruhi kadar oksigen terlarut dalam air yang penting bagi kelangsungan hidup larva. Semakin tinggi suhu maka semakin rendah kelarutan oksigen maka pada suhu yang ekstrim larva Anopheles spp. tidak dapat berkembangbiak dengan baik bahkan akan mengalami kematian. ${ }^{17}$

Nyamuk Anopheles spp. memerlukan genangan air, baik air tawar maupun air payau sebagai tempat perkembangbiakannya, tergantung pada jenis nyamuknya. Air tidak boleh tercemar dan harus selalu berhubungan dengan tanah. Tempat perkembangbiakan di perairan tawar berupa sawah, mata air, saluran irigasi, genangan di tepi sungai dan bekas lobang galian. Tempat perkembangbiakan ini dipengaruhi oleh faktor fisik maupun faktor biologi. ${ }^{18}$

Pengaruh sinar matahari dapat berbeda terhadap pertumbuhan larva nyamuk. Beberapa jenis Anopheles spp. menyukai tempat yang terbuka dan beberapa jenis Anopheles spp. yang lain menyukai tempat yang teduh. Anopheles punctulatus dan An. hyrcanus lebih menyukai tempat yang teduh sedangkan $A n$. sundaicus lebih menyukai tempat yang terbuka dan An. barbirostis dapat hidup baik ditempat yang terbuka maupun yang teduh. ${ }^{19}$ Pada penelitian yang dilakukan Indriani dkk dikatakan bahwa tidak ada pengaruh kondisi pencahayaan terhadap kepadatan larva Anopheles spp., sejalan dengan penelitian Leaua tidak ada hubungan antar pencahayaan tempat perkembangbiakan terhadap kepadatan dan spesies larva Anopheles spp. karena spesies yang ditemukan dapat pula hidup pada habitat dengan pencayaan terbuka maupun setengah terbuka. ${ }^{19} 20$

Salinitas habitat perkembangbiakan larva Anopheles di lokasi penelitian masing-masing habitat adalah sama yaitu $0 \%$. Hal ini menunjukan bahwa perairan yang merupakan habitat larva berkembangbiak termasuk jenis perairan air tawar. Seperti pada penelitian Ariati bahwa An. subpictus dapat hidup di air tawar maupun air payau, seperti pada parit dengan tepi yang berumput, kolam, mangrove, lapangan berumput dan bekas roda kendaraan berat dengan ketinggian 200 mdpl. ${ }^{21}$

Jarak habitat perkembangbiakan Anopheles ke pemukiman warga bervariasi 
untuk yang paling dekat yaitu \pm 7 meter dan paling jauh \pm 30 meter yang artinya jarak tersebut masih memungkinkan terjadinya penularan malaria karena masih dalam jangka terbang nyamuk Anopheles. Risiko penularan malaria juga tergantung pada jarak terbang nyamuk Anopheles, biasanya tidak lebih dari 1-2 $\mathrm{Km}$ dari tempat habitat perkembangbiakannya. Hal ini sejalan dengan penelitian Sanaky yang menyatakan bahwa jarak rumah terhadap habitat perkembangbiakan larva berpengaruh terhadap risiko penularan malaria ${ }^{22}$

Tumbuh-tumbuhan atau vegetasi yang ditemukan di habitat perkembangbiakan larva Anopheles berupa rumput-rumputan, kangkung dan padi. Keberadaan vegetasi dapat menyebabkan peningkatan kepadatan jentik karena menyediakan tempat bersembunyi dan makanan sehingga jentik dapat bertahan hidup. ${ }^{23}$

Ikan merupakan predator yang efektif dalam pengendalian vektor malaria dengan cara penebaran di laguna sebagai predator larva nyamuk. Hal ini sejalan dengan penelitian Setyaningrum yang menyatakan keberadaan ikan pada habitat perkembangbiakan mempengaruhi kepadatan jentik nyamuk, semakin banyak ikan maka kepadatan jentik semakin kecil demikian sebaliknya. ${ }^{24}$

Habitat perkembangbiakan larva Anopheles yang mempunyai kepadatan yang cukup tinggi yaitu kolam dan rawa, walaupun terdapat predator pemakan larva seperti ikan dan larva capung. Hal ini dapat dipengaruhi oleh keberadaan vegetasi yang terdapat pada habitat tersebut. Sesuai dengan pernyataan Rahayu menunjukan bahwa terdapat hubungan antara keberadaan vegetasi dengan densitas larva. Tumbuh-tumbuhan seperti lumut, dedaunan, dan pohon bakau mempengaruhi kehidupan jentik nyamuk. Dapat pula menjadi pelindung larva dari predator atau menaungi habitat agar tidak terkena langsung sinar matahari yang dapat menyebabkan peningkatan suhu air serta gangguan predator yang dapat mengurangi jumlah populasi larva nyamuk di habitat perkembangbiakan. ${ }^{25}$

\section{KESIMPULAN}

Dari penelitian yang dilakukan dapat disimpulkan bahwa jenis habitat perkembangbiakan Anophles di Kelurahan Kemelak Kabupaten OKU adalah rawa dan kolam dengan kepadatan larva berkisar 30110 larva perhabitat atau sekitar 3-11 larva percidukan. Suhu air pada habitat perkembangbiakan-berkisar $29^{\circ} \mathrm{C}-30^{\circ} \mathrm{C}$. Seluruh habitat perkembangbiakan Anopheles tidak terkena paparan sinar matahari langsung. Kadar garam pada habitat perkembangbiakan yaitu $0 \%$. Luas habitat berkisar $21 \mathrm{~m}^{2}-2400 \mathrm{~m}^{2}$, dengan memiliki pH masing- masing pada habitat yaitu 6 .

\section{SARAN}

Diharapkan pemerintah Provinsi, Kabupaten dalam hal ini Dinas Kesehatan dan Puskesmas setempat dalam hal ini petugas dalam program P2M dapat meningkatkan program pengendalian vektor secara berkala dan terpadu serta berkesinambungan dengan cara mengidentifikasi tempat potensial perkembangbiakan vektor malaria, pembasmian nyamuk dewasa serta larva Anopheles spp.

\section{UCAPAN TERIMA KASIH}

Terima kasih kepada yang terhormat Bapak Lasbudi P. Ambarita, M.Si sebagai reviwer dalam penulisan artikel ini. Kepala Balai Litbangkes Baturaja dan tim peneliti.

\section{KONTRIBUSI PENULIS}

RM dan HS sebagai kontributor utama. RM melakukan kurasi data dengan menyediakan data awal dan melengkapi data akhir, analisis data, investigasi, rancangan awal khusunya menulis draft awal, melakukan perbaikan setiap review, penelusuran refensi baru dan penyempurnaan daftar pustaka. HS membuat konsep, metodologi, investigasi dalam penyempurnaan draft awal sesuai dengan konsep dan penyempurnaan hasil review dan penelusuran refensi baru. $A, S$ dan LA membantu pencarian referensi draft awal, menyusun daftar pustaka. 


\section{DAFTAR PUSTAKA}

1. Aneesh EM, Thasia C, Laksmi $H$. Diversity and vectorial capacity of mosquitoes in Kuruva Island, Wayanad District, Kerala, India. J Zool Stud. 2014;1(4):16-22.

2. Kementerian Kesehatan Republik Indonesia. Profil Kesehatan Indonesia Tahun 2017. Jakarta : Kemenkes RI; 2018

3. Hamidian SA. Larval habitat characteristics of the Genus Anopheles (Diptera : Culicidae) and a checklist of mosquitoes in Guilan Province, Northern Iran. Iran J Arthropod Borne Dis. 2011;5(1):37-53.

4. Ndoen E, Wild C, Dale P, Sipe N, Dale $M$. Mosquito longevity, vector capacity, and malaria incidence in West Timor and Central Java, Indonesia. Interational Sch Res Netw Public Heal. 2012;2012:1-5.

5. Dinkes. 2019. Profil Kesehatan Kabupaten OKU.

6. Dinkes. 2017. Profil Kesehatan Kabupaten OKU

7. Santjaka, Aris. Malaria Pendekatan Model Kausalitas. Yogyakarta: Nuha Medika; 2013.

8. Indriani, Ishak, H. \& Russeng, S. S., (2014). Karakteristik Ekologi Habitat dan Sebaran Kepadatan Larva Anopheles di Kabupaten Kepulauan Selayar. [Online] Available at: http://pasca.unhas .ac.id/jumal/files/cf5 6a24f3c0 aa61b50cd7fe41e181f66.pdf. [Accessed 28 September 2020].

9. Pratama YG. Nyamuk Anopheles sp Dan Faktor Yang Mempengaruhi Di Kecamatan Rajabasa Lampung Selatan. J Majority. 2015;4(1):|20|).

10. Departemen Kesehatan RI. 2007. Ekologi dan Aspek Perilaku Vektor. Ditjen.PPM \& PL Departemen Kesehatan RI.Jakarta.

11. Sugiarto. Karakteristik Habitat Larva Anopheles spp. di Desa Sungai Nyamuk, Daerah Endemik Malaria di
Kabupaten Nunukan, Kalimantan Utara. Balaba.2016;12(1)|47-54|

12. Shinta, Supratman S dan Mardiana. Bionomik vektor malaria nyamuk Anopheles sundaicus dan Anopheles letifer di Kecamatan Belakang Padang, Batam, Kepulauan Riau. Bul Penel Kes. 2012;40(1):19-30(12)

13. Junus dkk.Jurnal vektor penyakit,2011:V(2)|1-14| Bionomik Anopheles di Desa Santu'un Kecamatan Muara Uya Kabupaten Tabalong Kalimantan Selatan

14. Willa R W' dkk, Penyebaran Kasus dan Habitat Perkembangbiakan Vektor Malaria di Kabupaten Sumba Timur Provinsi Nusa Tenggara Timur,Jurnal Ekologi Kesehatan Vol. 14 No 3, September $2015:$ 218-228(14).

15. Foster WA, Walker ED. 2002. Mosquitoes (Culicidae). In Mullen G, Durden L.eds. Med and Vet Entomol. San Deigo: Academic Press.)17)

16. Riana D dkk. Morfologi Siklus Hidup Epidemiologi kelas Insecta (nyamuk anopheles sp sebagai vector penyakit malaria). 2014.Akademi analis kesehatan.

17. Enim PPPMKM. Laporan pelaksanaan program pencegahan malaria Dinas Kesehatan Kabupaten Muara Enim tahun 2015.Kabupaten Muara Enim; 2015.

18. Harijanto, P.N. 2000. Malaria : Epidemiologi, patogenesis, Manifestasi Klinis dan Penanganan. Jakarta: EGC

19. Indriani dkk.(2014). Karakteristik Ekologi Habitat dan Sebaran Kepadatan Larva Anopheles di Kabupaten Kepulauan Selayar.Tesis.Program Studi Kesehatan Masyarakat Universitas Hasanuddin.

20. Leaua. (2013). Sebaran Kepadatan Larva dan Nyamuk Anopheles spp. Penyebab Penyakit Malaria di Desa Kumo Kecamatan Tobelo Kabupaten Halmahera Utara Provinsi Maluku Utara. Tesis. Pascasarjana Universitas Hasanuddin. Makassar.

21. Ariati Jusniar dkk. Sebaran Habitat Perkembangbiakan Larva Anopheles SPP di Kecamatan Bula, Kabupaten Seram Bagian Timur, Provinsi Maluku. 
2014. Jurnal Ekologi Kesehatan Vol.13 no 1 |10-14|.

22. Sanaky MJ, Daud AAA. 2014. The Relationship and Malaria Distribution Map in Ambon City, Indonesia. IJHSR.Vol 4. No 9. Tahun 2014. HIm. 249-257.

23. Zulfahrudin. 2011. Efektivitas Ikan Nila Dan Manipulasi Lingkungan Untuk Menurunkan Kepadatan Jentik Nyamuk Anopheles Sp. Di Laguna Kecamatan Tanjung Lombok Utara. Tesis. Program Pascasarjana Fakultas Kedokteran Universitas Gadjah Mada, Yogyakarta.
24. Widjaja, J. (2012). Pola Spasial Kasus Malaria Di Desasantu'un Kecamatan Muara Uya Kabupaten Tabalong Provinsi Kalimantan Selatan. Jurnal Vektor Penyakit, (1), Pp. 19-25.

25. Rahman R, Rahayu. Hubungan Karakteristik Lingkungan Breeding Site dengan Densitas Larva Anopheles di Wilayah Kerja Puskesmas Durikumba Kecamatan Karossa Kabupaten Mamuju Tengah. Skripsi. Fakultas Kesehatan Masyarakat universitas Hasanuddin Makasar; 2011. 